appointed until the University Court shall intimate to the Board of seven curators, in whom the patronage is to be vested, that the necessary buildings are erected and ready for occupation.

\title{
The Oxford Ophthalmological Congress
}

The Oxford Ophthalmological Congress held its eighth annual meeting at Oxford on July 12 and 13 last.

Members assembled on the evening of July 11 at Keble College, where, as in former years, accommodation had been kindly provided by the college authorities.

The Congress was again indebted to Professor Arthur Thomson for permission to conduct its proceedings in the Department of Human Anatomy in the University Museum.

The meeting, which was well attended, was opened with a short address of welcome by the Master, Mr. Sydney Stephenson.

The subject chosen for discussion was "The Correction of Errors of Refraction," the openers being Lieut.-Colonel Robert H. Elliot and Mr. Ernest Clarke.

Dr. George M. Gould (Atlantic City, N.J., U.S.A.), who had accepted the invitation of the council to open the discussion, was unavoidably prevented from attending owing to the serious illness of Mrs. Gould, but the manuscript of his address was read.

The following took part in the discussion:- Sir Anderson Critchett, Bt., C.V.O. (London), Mr. Harrison Butler (Leamington Spa), Dr. J. Gray Clegg (Manchester), Captain R. J. Coulter (Newport, Mon.) Dr. F. W. Edridge-Green (London), Miss Marion Gilchrist (Glasgow), Dr. D. V. Giri (Southampton), Dr. T. Eustace Harwood (London), Mr. John Hern (Darlington), Dr. George Young (Colchester), Dr. H. M. Traquair (Edinburgh), Lieut.-Colonel Hanford McKee, C.M.G. (Montreal) and Mr. S. Johnson Taylor (Norwich).

The Council having decided that a lecture shall be delivered annually at the meeting in memory of the late Mr. Robert Walter Doyne, founder and first Master of the Congress, had invited Dr. Gould to become the first lecturer, and the invitation having been accepted, Dr. Gould's enforced absence was the more to be regretted.

The medal which the Council has decided shall be presented to the lecturer will accordingly be sent to Dr. Gould.

The morning of the second day was devoted to papers and demonstrations, etc. A paper by Dr. Edridge-Green (London) on the relationship of the theory of vision to ophthalmology* was discussed by Lieut.-Colonel Elliot, Mr. Harrison Butler, Dr. Stewart Barrie, Dr. Traquair and Mr. Hern. Dr. George Young gave an 
interesting demonstration of his method of testing the colour threshold and its diagnostic value, and Mr. W. W. Sinclair described his experience of the test with especial reference to renal retinitis. Lieut.-Colonel Elliot showed lantern slides illustrating the direction in which the cataract may be dislocated by the coucher during the Indian operation. Dr. D. V. Giri read a paper on ring infiltration of the cornea in a case of purpura, and made some general observations on the different forms of corneal infiltration. Captain P. H. Adams spoke on retrobulbar neuritis with especial reference to prognosis.

In the afternoon Captain Adams showed cases of tuberculous disease of the eye, spring catarrh, Doyne's discoid cataract, "honeycomb" choroiditis, secondary carcinoma of the choroid, detachment of the retina cured by operation, and congenital anomalies. Dr. D. V. Giri showed a case of secondary pupil, and Mr. Cridland a large subretinal cyst. All were fully discussed by the meeting.

Mr. S. Johnson Taylor read a short paper on local anæsthesia in ophthalmic surgery, and Captain R. J. Coulter reported a case of bilateral interstitial keratitis following injury to one eye with especial reference to its medico-legal aspect.

The scientific museum contained interesting pathological specimens, skiagrams and new apparatus.

At the close of the discussion on July 12, Professor Sir William and Lady Osler entertained the members and their friends to tea, and the official dinner was held on the same evening at 8.15 in the hall of Keble College, when the Vice-Chancellor, the Very Reverend T. B. Strong, D.D., Dean of Christ Church, was in the chair, others present being the Warden of Keble, Professor Sir William Osler, Professor Arthur Thomson, Surgeon-General Sir Frederick Bradshaw, K.C.B., with many members of the Congress.

\section{ABSTRACTS}

\section{I.-CEREBRAL ABSCESS OF ORBITAL ORIGIN}

Elschnig, A. (Prague).-Cerebral abscess of orbital origin and its operative treatment. (Die orbitogene Hirnabszess und seine operation.) Klin. Monatsbl. f. Augenheilk., MarchApril, I9I4.

Elschnig has found little attention paid in the literature to this subject, and thinks that no case has been diagnosed in vivo and operated on with success. He gives notes of three cases, in 